Zofia Jakubów

Wydział Orientalistyczny, Uniwersytet Warszawski

\title{
Jak opisać dawne galicyjskie przedmieścia we współczesnym języku chińskim? Kognitywna analiza przekładów Sklepów cynamonowych Brunona Schulza
}

Kognitywne metody analizy tekstów kultury wzbudzają coraz większe zainteresowanie humanistów na całym świecie. Metodologia ta bardziej niż w literaturoznawstwie zakorzeniona jest w językoznawstwie i wciąż podejmowane są próby jej adaptacji do potrzeb badań literackich ${ }^{1}$. Metody kognitywne umożliwiają prowadzenie badań nad różnymi aspektami dzieła literackiego, m.in. obrazowaniem i stylistyką (oczywiście szerokich możliwości badania warstwy językowej dostarczają dobrze opracowane narzędzia językoznawcze), perspektywami prowadzenia narracji, kreacją bohaterów czy konstrukcją świata przedstawionego w ogóle.

W badaniach kognitywnych zagadnienia tradycyjnej poetyki są zwykle pojmowane jako szczegółowe aspekty większych procesów myślowych, np. teoria prototypu albo wysnute z psychologii postaci kategorie figury i tła mogą być stosowane zarówno w bada-

1 Wyjątkowe zasługi w tym zakresie przypisać należałoby Peterowi Stockwellowi, autorowi przetłumaczonej już na język polski Poetyki kognitywnej [Stockwell 2006]. Redaktorami ważnych, pionierskich prac są też m.in. Joanna Gavins i Gerard Steen [Gavins i Steen, red. 2003] oraz Geert Brône i Jeroen Vandaele [Brône i Vandaele, red. 2009]. 
niach stylistyki utworu, jak i w rozważaniach dotyczących budowy jego świata przedstawionego. W kontekście badań literackich lingwistyce kognitywnej zarzuca się czasem redukcjonizm, dążenie do zawarcia skomplikowanych procesów i zjawisk w prostych zasadach [Danaher 2006: 279]. Warto jednak docenić oferowane przez nią możliwości dokonywania dokładnych klasyfikacji elementów tekstu literackiego oraz analizy porównawczej krótkich jego fragmentów (przykładem może być poniższa analiza).

Jedną z najbardziej podstawowych koncepcji lingwistyki kognitywnej, której przeszczepienie na grunt badań literaturoznawczych wydaje się raczej naturalne, jest metafora pojęciowa. Poświęcona jej została słynna już praca George’a Lakoffa i Marka Johnsona, którzy definiują metaforę jako „rozumienie i doświadczanie pewnego rodzaju rzeczy w terminach innej rzeczy" [Lakoff i Johnson 1988: 27]. Najczęściej dotyczy to sytuacji, kiedy jakieś pojęcie lub system pojęć „nadaje strukturę metaforyczną innemu pojęciu” [Lakoff i Johnson 1988: 38] lub systemowi pojęć. Później opisali oni ten proces jako „przenoszenie elementów pomiędzy domenami pojęciowymi: z domeny źródłowej [...] do domeny docelowej [...]" [Lakoff i Johnson 1999: 58]. Domena źródłowa jest zazwyczaj lepiej znana człowiekowi z doświadczenia i postrzegana jako mniej skomplikowana. Jednym z klasycznych przykładów metafory pojęciowej jest mówienie o czasie $\mathrm{w}$ kategorii pieniądza [Lakoff i Johnson 1988: 29-31].

Związek pomiędzy elementami typowych metafor tworzy zazwyczaj „zbieżność doświadczenia” [Crisp 2003: 104]. Odwołując się do innego konwencjonalnego przykładu, można wskazać, że skojarzenie władzy z wysokością, znajdowaniem się ponad innymi (jak w idiomie „być górą”) wywodzi się z doświadczenia walki wręcz, w której zwycięzca przyjmuje taką właśnie pozycję [Crisp 2003: 100-101]. W niektórych rzadszych metaforach związek pomiędzy elementami opiera się na podobieństwie (np. kształtu). Często są to tzw. metafory wyobrażeniowe (image metaphors), konstruowane poprzez zestawienie dwóch obrazów. Peter Crisp, objaśniając to pojęcie, odwołuje się do haiku Ezry Pounda Na stacji metra. W tym tekście obraz twarzy pasażerów na tytułowej stacji skojarzony zostaje z obrazem płatków na gałęzi [Crisp 2003: 103-104]. 
Istnieją także związki bardziej skomplikowane niż metafory pojęciowe. Zostały one opisane przez Gilles’a Fauconniera i Marka Turnera. Elementy z co najmniej dwóch przestrzeni łączą się w tych związkach w nową „strukturę, której nie ma we wkładach [przestrzeniach wejściowych - Z.J.]" [Fauconnier i Turner 2019: 68]. Struktury te nazywa się zwykle w polskiej literaturze „amalgamatami pojęciowymi" [Jurewicz 2018: 9] (w oryginale conceptual blending, w niedawnym przekładzie książki Fauconniera i Turnera zaproponowano nazwę „mieszaniny pojęciowe” [Fauconnier i Turner 2019]).

Pojęcie amalgamatu może stanowić narzędzie opisu tekstów literackich, w których pojawiają się wyrafinowane, rozbudowane obrazy. Obfituje w nie twórczość Brunona Schulza, którą pod tym kątem analizowałam w artykule Kognitywna analiza opisu zmierzchu we fragmencie „Sklepów cynamonowych” Brunona Schulza [Jakubów 2018]. Chciałabym raz jeszcze odwołać się do podobnej metody, aby zbadać dwa chińskie przekłady Sklepów cynamonowych, biorąc pod uwagę zmiany, które tłumaczenie wywołuje w strukturach pojęciowych.

Pierwszy z przekładów dokonany został przez tłumaczącą z oryginału Tajwankę Lin Weiyun, w Polsce znaną jako Wei-Yun Lin-Górecka [Schulz 2016], drugi przez nieznającego języka polskiego chińskiego pisarza i tłumacza Lu Yuana [Schulz 2017]. Lu następująco opowiada o swojej pracy:

Nie byłem w stanie tłumaczyć z oryginału, więc znalazłem kilka angielskich przekładów. Przygotowałem też tekst oryginalny i kiedy przekłady angielskie różniły się między sobą, odwoływałem się do oryginału, który tłumaczyłem za pomocą translatora Google, tak że później rozumiałem już nawet trochę po polsku. [Nie 2020] $]^{2}$

Oprócz odmiennych kompetencji językowych i wykorzystanych tekstów źródłowych na efekty pracy translatorskiej może także z języka oryginału - Z.J. 
rzutować pochodzenie każdego z tłumaczy. Wei-Yun Lin-Górecka zaznacza, że na Tajwanie „używany jest $[. .$.$] «inny język chiński»”$ [Lin-Górecka 2013: 116]. Opis różnic pomiędzy językiem chińskim używanym po dwóch stronach Cieśniny Tajwańskiej wykraczałby poza ramy niniejszego artykułu. W kontekście badania metafor i amalgamatów pojęciowych, które w utworze literackim ujawniają się w dużej mierze na poziomie semantyki wyrazów i frazeologii, taki opis byłby co najmniej niedoskonały, gdyż tego typu odmienności nie są ostre, a język w obu przypadkach nie jest w tym zakresie monolityczny. Odrębność kulturowa ChRL i Tajwanu oraz odległość geograficzna mogą jednak oczywiście potęgować różnice pomiędzy obydwoma analizowanymi przekładami.

Trudno się spodziewać, że przypadkowo zagadnięty na ulicy Chińczyk okaże się czytelnikiem prozy Schulza, ale twórczość polsko-żydowskiego pisarza nie jest w Chinach całkowicie nieznana. Tamtejsi krytycy chętnie interpretują go, porównując do Franza Kafki [Wu 2010: 255-258], jednak stopniowo zaczynają doceniać także jego oryginalność. Wu Lan wspomina o spotkaniu zorganizowanym w Pekinie w 2009 roku z okazji opublikowania tomu prozy Schulza w przekładzie Yang Xiangronga [Wu 2010: 253-254]. Oprócz literaturoznawców z kilku ważnych uniwersytetów wziął w nim udział jeden z najsłynniejszych współczesnych chińskich pisarzy - Yu Hua. Yu napisał przedmowę do omawianego wówczas przekładu, a wcześniej jeszcze, w latach 90., włączył utwór Schulza Ptaki do zbioru zatytułowanego Wennuan de lücheng: yingxiang wo de 10 bu duanpian xiaoshuo (Ciepła podróż: dziesięć opowiadań, które na mnie wptynęty). Jego zaangażowanie zdecydowanie przyczyniło się do wzrostu rozpoznawalności autora Sklepów cynamonowych w Chinach [Fu i Wang 2008: 130]. Dwa lata po pekińskim spotkaniu artykuł poświęcony przekładowi Schulza ukazał się w renomowanym czasopiśmie „Mingzuo Xinshang” [Yang 2011].

Wei-Yun Lin-Górecka podkreśla:

Myślę, że komuś, kto nie zna języka chińskiego, trudno sobie wyobrazić, ile wysiłku trzeba, żeby przetłumaczyć prozę Schulza na ten język. Wynika to głównie z tego, że język polski i język chiński są zupełnie inne. [Lin-Górecka 2013: 114] 
Tłumaczka wymienia przede wszystkim różnice gramatyczne, w szczególności składniowe, ale także te związane z warstwą semantyczną wyrazów: obecność mniejszej liczby synonimów w języku chińskim niż w języku polskim ${ }^{3}$, niemożliwą do przełożenia wieloznaczność czy fakt, że niektóre z wykorzystywanych przez Schulza słów to niewystępujące w języku chińskim zapożyczenia z języków europejskich. Lin-Górecka wspomina także o trudnościach, których chińszczyzna nastręcza w tworzeniu neologizmów czy izolowaniu pewnych znaczeń w sposób naturalny wyodrębnianych w języku polskim [Lin-Górecka 2013: 114-117].

Mimo wszystkich tych przeszkód tłumaczka zachowuje dużą dozę optymizmu i deklaruje wiarę w możliwość dokonania satysfakcjonującego przekładu, przyrównując osiągalne w ten sposób porozumienie między użytkownikami różnych języków do sekretnego uścisku dłoni pod stołem [Lin-Górecka 2013: 118]. Takim optymizmem wykazują się w najogólniejszym sensie także zwolennicy lingwistyki kognitywnej. Paradygmat ten, choć odrzuca typową dla strukturalizmu wiarę w uniwersalne schematy rządzące kulturą i językiem, wiąże znaczenie z ludzkim doświadczeniem [Rojo i Ibarretxe-Antuñano 2013: 7], często fizycznym, codziennym, a więc chociaż geograficznie i kulturowo zróżnicowanym, jednak stosunkowo łatwym do wytłumaczenia i w wielu przypadkach zbieżnym. Kognitywiści uważają język za „produkt umiejętności poznawczych” [Rojo i Ibarretxe-Antuñano 2013: 11], ponieważ człowiek ,tworzy kategorie mentalne i językowe w ramach ograniczeń ustanawianych przez ciało, filtrując je przez sito kultury, i na podstawie konkretnych doświadczeń [Rojo i Ibarretxe-Antuñano 2013: 11].

Odnosząc się bezpośrednio do przekładu, Ana Rojo i Iraide Ibarretxe-Antuñano wskazują, że najważniejsze jest w nim stworzenie funkcjonalnej w języku docelowym całości. Nie powinien on natomiast opierać się na mechanicznym odwzorowywaniu doświadczeń z tłumaczeniem analizowanego tekstu, nie zaś do potwierdzonych badaniami językoznawczymi, obiektywnie istniejących pomiędzy obydwoma językami odmienności. 
poszczególnych elementów językowych. Ekwiwalencja ma być obecna $\mathrm{w}$ „złożonym zbiorze połączeń w umyśle tłumacza” [Rojo i Ibarretxe-Antuñano 2013: 13].

Choć kognitywiści często badali „połączenia w umyśle” na drodze eksperymentalnej, to literaturoznawca nieuzbrojony w maszyny do monitorowania pracy mózgu także może wykorzystać ich dorobek. Jednym z najważniejszych autorytetów w zakresie kognitywnych analiz przekładu jest Elżbieta Tabakowska, która opisuje m.in. sposób badania ekwiwalencji z perspektywy obrazowania. Tabakowska proponuje analizę jednostek tekstu

pokrywających się z pojęciem „obrazu” w Langackerowskiej teorii obrazowania w języku [...] jednostka taka byłaby pojedynczą „sceną” widzianą przez jakiegoś jednego „konceptualizatora” w jakimś jednym momencie. [Tabakowska 2001: 99]

Podziela ona pojawiający się u Rojo i Ibarretxe-Antuñano pogląd o braku związku ekwiwalencji z odwzorowywaniem elementów przystających do siebie „na [...] poziomie «językowym»” [Tabakowska 2001: 100]. W jej ujęciu ekwiwalencja powinna być realizowana na poziomie obrazowania; badaczka definiuje ją jako „zbieżność obrazów” [Tabakowska 2001: 100].

Przedmiotem niniejszej analizy jest właśnie pojedynczy obraz: zawarty w opowiadaniu Schulza Sierpień opis bujnej roślinności rozwijającej się w jednym z podmiejskich ogrodów oraz przekłady tego opisu na język chiński.

A ku parkanowi kożuch traw podnosi się wypukłym garbem-pagórem, jak gdyby ogród obrócił się we śnie na drugą stronę i grube jego chłopskie bary oddychają ciszą ziemi. Na tych barach ogrodu niechlujna, babska bujność sierpnia wyolbrzymiała w głuche zapadliska ogromnych łopuchów, rozpanoszyła się płatami włochatych blach listnych, wybujałymi ozorami mięsistej zieleni. Tam te wyłupiaste pałuby łopuchów wybałuszyły się, jak babska szeroko rozsiadłe, na wpół pożarte przez własne oszalałe spódnice. Tam sprzedawał ogród za darmo najtańsze krupy dzikiego bzu, śmierdzącą mydłem, grubą kaszę 
babek, dziką okowitę mięty i wszelką najgorszą tandetę sierpniową. [Schulz 1989: 7]

Strukturę opisu roślinności ogrodu można określić jako skomplikowany amalgamat pojęciowy o kilku przestrzeniach wejściowych. Pierwsza to oczywiście przestrzeń bujnej roślinności w ogrodzie. Konstytuują ją wyrazy i frazy, takie jak: „parkan”, „kożuch traw”, „ogród”, „ziemia”, „bujność, „łopuchy”, „blachy listne”, „zieleń”, „dziki bez”, „babki”, „mięta”.

Drugą przestrzeń nazwać można przestrzenią opisu wiejskiej ludności. Zaliczyć do niej należy obraz obracającego się we śnie na drugi bok, oddychającego w sposób widoczny poprzez unoszenie się barków chłopa, którego zgięte plecy stanowią pojawiający się w pierwszych słowach „garb”. Występujące w kolejnym zdaniu przymiotniki „babski” $i$ „niechlujny” zapowiadają następny obraz: ubrane w spódnice „babska szeroko rozsiadłe”. Są to wiejskie przekupki, o czym czytelnik wnioskuje z zamykającego opis fragmentu poświęconego sprzedawaniu tanich, tandetnych towarów.

Trzecia przestrzeń to odniesienia do rzeźby terenu. W tekście najpierw pojawia się „pagór”, do tej przestrzeni wejściowej można zaliczyć również wyraz „ziemia” oraz frazę „głuche zapadliska”.

Kolejną przestrzeń budują skojarzenia związane z dzikim zwierzęciem - włochatym, posiadającym mięsisty ozór, które oszalałe pożera spódnice przekupek. Wspomniany w pierwszym zdaniu garb może być elementem wspólnym czwartej przestrzeni z przestrzenią, w której mieści się opis śpiącego chłopa.

Ostatnia przestrzeń zarysowuje się w sposób bardziej subtelny, ponieważ w pełni ukształtuje się dopiero w dalszym fragmencie tekstu, opowiadającym o obłąkanej Tłui. Zachowanie chorej umysłowo dziewczyny porównane tam będzie do odprawianej przez sierpień pogańskiej orgii, zaś ona sama - do pogańskiego bożka. W analizowanym opisie pojawiają się sugestie, że ogrodem rządzi jakaś nadnaturalna siła, sierpniowy żywioł. Siła ta nazwana zostaje „bujnością. Bujność „wyolbrzymia” i „panoszy się”. Być może wcielona zostaje w zwierzę z czwartej przestrzeni. Słowo „panoszyć się” stanowi jednak wyraźną antropomorfizację, która odsyła odbiorcę poza skojarzenie ze zwyczajnym przedstawicielem fauny. Trafne 
może być odniesienie do „pogańskich” bóstw, często wyobrażanych jako zwierzęta lub istoty o cechach częściowo zwierzęcych.

Przestrzeń generyczną, czyli zawierającą elementy wspólne dla wszystkich tworzących amalgamat przestrzeni wejściowych, stanowią ta sama przestrzeń fizyczna (półdzikie podmiejskie tereny), kształt (kształt ogrodu wraz z porastającą go roślinnością porównywany jest do gór i dolin oraz do kształtu ciał i ubrań chłopów lub dzikiego, posiadającego cechy nadnaturalne zwierzęcia) oraz element nieprzejrzystości, utrudnionej widoczności (bujna roślinność, głuche, zarośnięte zapadliska, tłumek wiejskich przekupek, tonących w swoich szerokich spódnicach, czający się w zaroślach drapieżnik, trudna do zlokalizowania siła). Ponadto przestrzenie łączy dynamika obrazu, jako że wszystkie elementy sprawiają wrażenie zastygłych w ruchu. Chłop leży i śpi, przekupki siedzą, zajęte handlem, zwierzę wysuwa ozór i pożera zdobycz, nawet w przypadku pagóra i zapadlisk oraz samej roślinności wyraźnie zaznaczone zostało, że przybranie określonego kształtu poprzedził ruch, nierzadko intensywny. „Podnoszenie się” należy odnieść do traw i do pagóra, zapadliska są produktem procesu „wyolbrzymiania” (rozrostu, rozszerzania się) sierpniowej bujności, łopuchy „wybałuszyły się".

Amalgamat można zatem opisać w następujący sposób: w podmiejskiej przestrzeni zastygła w ruchu ledwie widoczna, skryta wśród roślin istota o nieregularnym, falującym kształcie i nieokreślonym statusie przynależności do kategorii istot żywych.

Proza Schulza jest niezwykle złożona i nawet powyższy, dość rozbudowany, schemat nie obejmuje wszystkich elementów wykorzystanych do stworzenia obrazu ogrodu. W kontekście niniejszej analizy, szczególnie w odniesieniu do istotnego problemu wspomnianego powyżej niejasnego statusu przynależności przedmiotu opisu do kategorii istot żywych, warto zwrócić jeszcze uwagę na metaforę „pałuby łopuchów”. „Pałuby” to słowo rzadko występujące we współczesnej polszczyźnie. W przypisie do polskiego wydania Sklepów cynamonowych zdefiniowane zostało jako 'kukły o topornych kształtach' [Schulz 1989: 7].

Kognitywiści uważają, że jedną z podstawowych czynności umysłu jest kategoryzowanie, które prowadzi do powstawania 
sieci radialnych. Ludzie umiejscawiają poszczególne pojęcia w ich centrum lub na ich peryferiach. Opisując to zjawisko, Peter Stockwell [2006: 40-41] posługuje się przykładem kategoryzowania owoców. Większość Europejczyków poproszona o wymienienie nazwy jakiegoś owocu poda jabłko lub pomarańczę, ponieważ są one w ich opinii najlepszymi, centralnymi przykładami owoców, posiadają najwięcej cech przypisywanych kategorii owocu w ich kręgu kulturowym. Do przykładów peryferyjnych należałyby w tym przypadku pomidor lub awokado. Wyodrębnienie zjawiska kategoryzacji jest fundamentem teorii prototypu, stosowanej szeroko w analizach kognitywnych, m.in. w badaniach gramatyki, w których pewne struktury, sposoby użycia wyrazów itd. uznaje się za prototypowe, czyli centralne w sieci radialnej. Na gruncie literackim dewiacyjność, czyli wykorzystywanie rozwiązań nieprototypowych (np. w warstwie stylistycznej), może być nośnikiem znaczeń i zwracać uwagę czytelnika, w szczególności wywoływać uczucie niepewności, konsternację [Stockwell 2006: 87-93].

Odbiorca komunikatu językowego ma określone tzw. wymiarami tematyczności oczekiwania co do podmiotu zdania. W kontekście analizowanego opisu ogrodu szczególne znaczenie ma wymiar empatii. Stockwell [2006: 88] następująco szereguje podmioty od najbardziej do najmniej prototypowego: „mówiący $\rightarrow$ słuchacz $\rightarrow$ człowiek $\rightarrow$ zwierzę $\rightarrow$ przedmiot fizyczny $\rightarrow$ pojęcie oderwane". We fragmencie opowiadania Schulza podmioty zdań należałoby umieścić nisko na skali empatii: „kożuch traw”, „ogród” (dwa razy), „,chłopskie bary”, „bujność, , „pałuby”. Są to albo „przedmioty fizyczne” (Stockwell nie wyodrębnia kategorii roślin), albo „pojęcia oderwane”. Chłop pojawia się tylko na zasadzie metonimii („chłopskie bary”), „babska” lączą się z nieprototypową dla wyrażania czynności częścią mowy - imiesłowem („rozsiadłe”) i pełnią w zdaniu funkcję okolicznika sposobu.

Metafora „pałuby łopuchów” jest interesująca właśnie z perspektywy skali empatii. Porównanie łopuchów do pałub pozwala na ich radykalną antropomorfizację - dostrzeżenie w ich liściach kształtu ludzkiego jest dalekie od oczywistości i umożliwia stworzenie bardzo oryginalnej metafory. Natychmiast przywołany zostaje 
jednak obraz wiejskich przekupek. Skojarzenie ich z pałubami powoduje ich dehumanizację.

Obiekty takie jak kukły wywołują lączone także z prozą Schulza [Wojda 2009:187] odczucie identyfikowane jako Unheimlichkeit, czyli niesamowitość [Iversen 2006: 287]. Posługując się językiem kognitywistów, można powiedzieć, że uczucie to powstaje w sytuacji, gdy umysł napotyka trudności w określeniu kategorii przynależności obiektu, w umieszczeniu go w sieci radialnej, szczególnie, kiedy dotyczy to kategorii „człowiek” albo „istota ożywiona”. Takie wrażenie powstawać może np. „na widok robota, który wygląda jak żywy, lub robotycznego zachowania u człowieka" [Iversen 2006: 287]. Czytelnik Schulza odczuje oczywiście niesamowitość najpełniej podczas lektury Traktatu o manekinach, ale także w analizowanym opisie ogrodu pisarz wciąga go w grę antropomorfizacji i dehumanizacji. Jej elementem jest niskie umiejscowienie aktywnych przecież w pewien sposób podmiotów na skali empatii. Do omawianej tu szczegółowo metafory „pałuby łopuchów” należą także słowa „wyłupiaste” $i$ „wybałuszyły się”. W polskiej frazeologii najbardziej konwencjonalne jest ich połączenie z wyrazem „oczy” (być może kształt oczu przypominał pisarzowi owocostan łopianu). Wybałuszone oczy kojarzą się ze zmienionym stanem psychicznym, pobudzeniem, strachem, osłupieniem. Uczucie niepokoju, wywołane przez to skojarzenie, musi wzrastać, kiedy czytelnik napotyka kolejny dysonans, bo tradycyjne „zwierciadło duszy”, tutaj zastygłe jakby w emocjonalnej odpowiedzi na jakieś bodźce, przynależy do martwych kukieł.

To balansowanie na granicy kategorii niezwykle trudno oddać w przekładzie. Mimo to misterna struktura wyobrażeniowa zbudowana w Schulzowskim opisie ogrodu została w znacznej mierze odtworzona przez Wei-Yun Lin-Górecką. Oczywiście nieuniknione było wprowadzenie do przekładu nowych skojarzeń i pominięcie niektórych elementów obecnych w oryginale.

Wiele różnic pomiędzy oryginalnym opisem Schulza a tłumaczeniem Wei-Yun Lin-Góreckiej związanych jest właśnie z problemem stopnia ożywienia i aktywności występujących w tekście obiektów. Takie rozbieżności zarysowują się już w pierwszym zdaniu, w którym łączą się przestrzenie roślinności, rzeźby terenu 
i opisu śpiącego chłopa. W oryginale „kożuch traw podnosi się wypukłym garbem-pagórem”. W przekładzie zupełnie pominięty został wyraz "garb”, który stanowi element antropomorfizacji obrazu, słowo „podnosić się” zostało natomiast oddane jako long [Schulz 2016]. O ile podnieść się może człowiek (np. przebudzony ze snu), o tyle dokładniejszym tłumaczeniem long byłoby 'puchnąć, wybrzuszać się, co stanowi raczej proces niż celową czynność, którą można by przypisać istocie ożywionej. Fraza „oddychają ciszą ziemi” została rozbita na dwa zdania: yu dadi rongwei yiti, zai jijing zhong huxi [Schulz 2016], czyli: „stapiają się w jedno z ziemią i oddychają w ciszy/spokoju”. Także tutaj roślinność / pagór / bary są mniej aktywne w stosunku do ziemi niż w oryginale - tam korzystają z jej zasobów (oddychają jej ciszą). W przekładzie ziemia i cisza nie są już im podporządkowane - ziemia jest umiejscowiona $\mathrm{z}$ nimi na równi, cisza staje się ich otoczeniem.

Podmiot i orzeczenie następnego zdania zostały przetłumaczone dość wiernie, mimo to fragment ten częściowo utracił swą wyrazistość; efekt hiperboli: „bujność [...] wyolbrzymiała” został oddany jako „wybujała witalność zrodziła” (wangsheng de [...] shengmingli zizhang chu) [Schulz 2016]. Pominięte zostały natomiast całkowicie „zapadliska”, które zamieniono na „połać/przestrzeń” (yi pian) [Schulz 2016], likwidując w ten sposób znaczną część przestrzeni wejściowej rzeźby terenu. Usunięty został również przymiotnik „głuchy”. W efekcie pozostało tylko określenie „tłusty, przerośnięty” (feida) [Schulz 2016] - ten element przestrzeni rzeźby terenu zamieniony został na element przestrzeni roślinności.

W dalszej części zdania „bujność” traci funkcję podmiotu. W tekście polskim bujność „rozpanoszyła się”. Czasownik ten został przełożony jako zhipei, czyli raczej 'rozporządzać czymś, kontrolować, a podmiotem są tu „liście” (yepian) i „zielone języki” (lüse shetou) [Schulz 2016]. Osłabione zostają zatem odniesienia do manifestującej się w ogrodzie nadnaturalnej siły, pogańskiego bóstwa. Bujność traci rolę sprawczą na rzecz elementów z przestrzeni wejściowej roślinności, a samowolność, nadużycie wpisane w wyraz „panoszyć się”, stanowiące element karnawałowego, pogańskiego żywiołu, zostają zastąpione bardziej racjonalnym, chłodnym zhipei. 
Wei-Yun Lin-Górecka pomija całkowicie w tłumaczeniu metaforę „pałuby łopuchów”, rezygnując tym samym z wprowadzanej przez nią antropomorfizacji obrazu. W poświęconym przekupkom fragmencie osłabiane są także skojarzenia z nadprzyrodzoną siłą i orgią sierpnia. W tekście oryginalnym babska są pożerane przez oszalałe spódnice. W przekładzie są natomiast „pochłaniane przez falujące rąbki spódnic” (bei qifu de qunbai tunmo) [Schulz 2016]; tunmo oznacza 'pochłaniać/połykać' i wskazuje na czynność mniej gwałtowną niż pożeranie, niekoniecznie też wykonywaną przez zwierzę. Uszczuplona zostaje więc przestrzeń dzikiego zwierzęcia. Wyraz qifu bywa czasem odnoszony do sfery uczuć, jak we frazie xinchao qifu, która opisuje zmienny nastrój, niepokój, ale nawet wówczas wyraża mniejsze natężenie emocji niż szaleństwo. Przeważnie jednak słowo to opisuje falujący ruch lub kształt. Z przestrzeni zwierzęcia lub nadprzyrodzonej siły zostaje zatem odjęty kolejny element. Warto także zwrócić uwagę na występujący w tekście oryginalnym oksymoron „sprzedawać za darmo”, łączący się ze wspomnianym szaleństwem, karnawałowym odwróceniem pogańskiej orgii. Zostaje on pominięty w przekładzie: ogród już nie sprzedaje, a „dostarcza za darmo” (mianfei tigong) [Schulz 2016] swoje roślinne towary.

Różnica pomiędzy tekstem oryginalnym a tłumaczeniem Wei-Yun Lin-Góreckiej polega więc głównie na rzadszym stosowaniu zabiegów antropomorfizacji i ożywienia, dodaniu elementów do przestrzeni wejściowej roślinności i osłabieniu skojarzeń związanych z przypisywaną sierpniowej bujności nadprzyrodzoną siłą. Uszczuplone zostają także przestrzenie wejściowe odnoszące się do rzeźby terenu i dzikiego zwierzęcia. Mimo wielkiej sprawności tłumaczki amalgamat staje się więc w przekładzie nieco uboższy, zmniejsza się też uczucie niepokojącej niesamowitości u odbiorcy opisu.

Wiele rozwiązań występujących u Wei-Yun Lin-Góreckiej powtarza się w przekładzie Lu Yuana, warto jednak wyszczególnić także kilka znaczących różnic. Lu również tłumaczy „podnosić się” jako long [Schulz 2017] i pomija wyraz „garb”, ale wierniej niż Lin-Górecka, zachowując oryginalne relacje składniowe, oddaje frazę „oddychają ciszą ziemi”: „wdychają ciszę ziemi” (xiru nitu de ningmi) [Schulz 2017]. Bujność sierpnia to u niego „bujny sierpień” 
(shengji de bayue) [Schulz 2017] - to thumaczenie nie zmienia przestrzeni wejściowej sierpniowego żywiołu. Nieco zaskakujący jest przekład przymiotnika „babska” w złożeniu „babska bujność”: „pełna wdzięku dojrzałej kobiety” (fuyu chengshu furen de fengyun) [Schulz 2017]. Wyraz „wdzięk” (fengyun), zawierający element wyrafinowania, wprowadza dysonans w przestrzeni wejściowej zawierającej opis wiejskiej ludności. Nie przystaje też do wyrazu „niechlujny”, który jednak w tłumaczeniu Lu został zmieniony na „zmierzwiony” (pengluan) [Schulz 2017] - słowo konwencjonalnie używane do opisu m.in. trawy, przez co wywołujące słabszy efekt antropomorfizacji i mniej rażące w połączeniu z „wdziękiem” kobiet.

Podobnie jak u Wei-Yun Lin-Góreckiej w przekładzie Lu Yuana następuje złagodzenie hiperboli w wyrazie „wyolbrzymiać” („rozrastać się" [manyan] [Schulz 2017]). Lu zachowuje w dalszej części tekstu element związany z rzeźbą terenu, jednak jego „ciche doliny” (chenji shangu) [Schulz 2017] przywołują obraz obiektu o znacznie większej skali niż „głuche zapadliska”. W tym samym zdaniu, inaczej niż w przekładzie Lin-Góreckiej, „bujny sierpień” utrzymuje rolę podmiotu, choć „panoszyć się” także przetłumaczone zostało jako zhipei. Na skutek pominięcia przymiotnika „włochaty” uszczupleniu ulega przestrzeń wejściowa zwierzęcia. Jednocześnie dochodzi do wyeksponowania nienależącej do amalgamatu, w oryginale bardzo subtelnej metafory „blachy listne”. Blacha jest oczywiście metalowa, ale kojarzy się z blaszką liścia. Lu przetłumaczył to złożenie jako xibo ban nongmi [...] de [... ] ye [Schulz 2017], czyli „liście zwarte jak cynfolia”. Na takie wyeksponowanie nie zdecydowała się Lin-Górecka, która użyła po prostu wyrazu yepian [Schulz 2016], czyli właśnie „blaszka liściowa” (ye to 'liść', a pian to zwykle 'cienki kawałek czegos'). Lu pomija także metaforę „pałuby łopianu”, zastępując ją bardziej dosłownymi, należącymi do przestrzeni wejściowej roślinności „wystającymi/wybrzuszonymi rzepami (owocostanami) łopianu" (tuqi de ciguo) [Schulz 2017], które już nie wybałuszają się, tylko po prostu „wypełniają całą przestrzeń” (chongchi bian ye) [Schulz 2017].

W kolejnym zdaniu rzeczownik „babska” został przetłumaczony jako nongfumen [Schulz 2017], czyli chłopki. Jest to oczywiście 
słowo inaczej nacechowane, wywołujące inne skojarzenia, ale nie zmienia wiele $\mathrm{w}$ konstrukcji amalgamatu (podobnie zresztą jak również nie do końca uzasadnione „kobiety o obfitych piersiach i pełnych biodrach" (fengru-feitun de funü [Schulz 2016] u Wei-Yun Lin-Góreckiej). Wyraźne zmiany następują w tłumaczeniu fragmentu „na wpół pożarte przez własne oszalałe spódnice”, w którym uszczuplone zostają przestrzenie dzikiego zwierzęcia i nadnaturalnej siły. Kobiety zamiast „pożarte” zostają „owinięte” (guo) [Schulz 2017], a spódnice „unoszą się / powiewają” (feidang) [Schulz 2017]. Podobnie jak Lin-Górecka Lu Yuan pomija oksymoron „sprzedawać za darmo”, również przekładając go jako „dostarczać za darmo” (mianfei tigong) [Schulz 2017].

W przekładzie Lu Yuana zachowany został wysoki stopień ożywienia części elementów, które u Wei-Yun Lin-Góreckiej traciły aktywną rolę. To pozwoliło zaakcentować witalność natury, jej nadprzyrodzoną siłę i w większym stopniu oddać oryginalną niesamowitość opisu. Lu w mniejszym zakresie naruszył także przestrzeń wejściową rzeźby terenu, jednocześnie dwa razy usuwając elementy z przestrzeni dzikiego zwierzęcia, które zachowała Lin-Górecka. Jego tłumaczenie w wielu miejscach jest wierniejsze, Lu stara się zachować jak najwięcej wyrazów i fraz z oryginału, jednak częściej zdarza mu się zaburzać porządek przestrzeni wejściowych, przez co przekład sprawia wrażenie mniej konsekwentnego. Lin-Górecka rezygnuje z pewnych części amalgamatu, ale nie eksponuje nadmiernie elementów $\mathrm{w}$ oryginale jedynie subtelnie zaznaczonych (jak metafora „blachy listne”), nie zdarza jej się także wprowadzać do przestrzeni wejściowych dysonansów, takich jak ten, który spowodował Lu, umieszczając w tekście frazę „wdzięk dojrzałej kobiety".

W obydwu przekładach wyraźne zmiany wprowadzone zostały w katalogu sprzedawanych przez ogród towarów, mają one jednak mniejsze znaczenie dla struktury amalgamatu pojęciowego. U Wei-Yun Lin-Góreckiej pominięte zostało słowo „krupy” w wyrażeniu „najtańsze krupy dzikiego bzu”, tak samo jak „gruba kasza” w wyrażeniu „gruba kasza babek”. Co więcej, babki zamiast „śmierdzieć mydłem” - „pachną mydłem” (wen qilai you gu feizao wei) [Schulz 2016]. Lu Yuan również pomija wyraz „krupy”, a następnie wyod- 
rębnia „śmierdzące mydło” (chou feizao) [Schulz 2017] jako inny towar i próbuje oddać „grubą kaszę” jako „zawiesisty kleik” (chouhou de [... zhou) [Schulz 2017], co w zasadzie należałoby uznać za błąd. Lin-Górecka prawdopodobnie przyjęła, że niemożliwe jest przekazanie metafor związanych z kaszą ze względu na różnice kulturowe: kasza, która musiała rzeczywiście być jednym z podstawowych towarów na galicyjskim targowisku, Chińczykom i Tajwańczykom mogłaby wydawać się egzotyczna, więc próba zachowania oryginalnego znaczenia wymagałyby peryfraz lub przypisów. Tłumaczenie frazy „gruba kasza” jako „zawiesisty kleik” jest całkowitą zmianą domeny źródłowej metafory.

Lu Yuan wierniej niż Wei-Yun Lin-Górecka oddał wyrażenie „dzika okowita mięty”: „dziki, mocny alkohol miętowy” (kuangfang de liexing bohe jiu) [Schulz 2017]. Lin-Górecka przetłumaczyła ten fragment jako: „mięta o zapachu mocnego alkoholu” (daizhe liejiu qiwei de bohe) [Schulz 2016].

Zastanawiać może, dlaczego Wei-Yun Lin-Górecka pominęła w swoim przekładzie „smród mydła”. Przypuszczalnie Polakowi określenie to może się kojarzyć z surowym zapachem specyficznego rodzaju szarego mydła, którego azjatycki odbiorca prawdopodobnie nie zna. W zasadzie jednak zamiana „smrodu” na „zapach” jest w dużej mierze subiektywnym wyborem tłumaczki. Przecież także wielu Polakom wyraz „mydło” przywodzi na myśl wyłącznie przyjemny zapach; nawet wspomniane szare mydło bywa pod tym względem różnie oceniane. $Z$ pewnością w $C h R L$ i na Tajwanie znajdą się czytelnicy, którzy nie lubią zapachu niektórych środków czyszczących. Co więcej, „śmierdzące mydło” (chou feizao) [Schulz 2017] zostało zachowane w thumaczeniu Lu Yuana, chociaż wątpliwe jest, by doświadczenia czytelników z ChRL z mydłem były znacznie bardziej zbieżne z doświadczeniami Polaków niż doświadczenia Tajwańczyków.

Przykład ten prowadzi do refleksji nad rolą jednostki w procesie tłumaczenia i jego interpretacji. Na podobny problem interpretacyjny - tym razem związany nie z decyzją o pominięciu frazy, a z jej nieco kontrowersyjnym tłumaczeniem - natrafić możemy w pierwszym zdaniu opisu. Wei-Yun Lin-Górecka oddaje wyrażenie „kożuch traw” jako cao zuocheng de pi dayi [Schulz 2016], czyli 
„kożuch (dosł. 'płaszcz ze skóry') wykonany z trawy”. Podobnie ten fragment przełożył Lu Yuan: „kożuch/płaszcz ze skóry z zielonej trawy” (qingcao de pidayi) [Schulz 2017]. „Kożuch” to wyraz wieloznaczny; w połączeniu z określeniem „traw” aktywowane jest raczej znaczenie 'drobna roślinność, liście lub zanieczyszczenie pokrywające powierzchnię wody' [Stownik języka polskiego $P W N]$, dlatego w niniejszej analizie wyrażenie zostało uznane za część przestrzeni wejściowej roślinności. Ewentualnie można by się tu nawet dopatrywać przejścia w przestrzeń rzeźby terenu poprzez skojarzenie ze zbiornikiem wodnym, stawem. Dla autorki artykułu, natywnej użytkowniczki języka polskiego, tłumaczenie Lin-Góreckiej jest zaskakujące, choć przecież wykorzystane przez nią znaczenie wyrazu „kożuch” umieszczono w Stowniku języka polskiego $P W N$ na drugim miejscu, podczas gdy 'drobna roślinność [... ]' jest dopiero na czwartej pozycji.

Aby ustalić, które ze znaczeń wyrazu „kożuch”, kiedy występuje on we frazie „kożuch traw”, jest najbardziej prototypowe w odbiorze użytkowników języka polskiego, należałoby przeprowadzić badania na reprezentatywnej ich grupie. Ponieważ jednak również kognitywiści uznają, że interpretacja przekładu może być różna w przypadku różnych czytelników i sama w sobie stanowi swoisty amalgamat [Boase-Beier 2011: 68-69], uwzględniony tutaj zostanie jedynie sposób odczytania zaproponowany przez autorkę artykułu. Trudno sobie wyobrazić tak szczegółowe badania w praktyce przekładu - nie podejmują się ich nigdy tłumacze, również czytelnicy opierają się tylko na własnej kompetencji językowej i skojarzeniach. Bazująca na takich hipotetycznych badaniach, „uśredniona” interpretacja stanowiłaby twór czysto teoretyczny, wyabstrahowany z pracy umystu realnych osób.

Do tego problemu odnosi się także Tabakowska [2001: 102]:

[... ] różnice w inwentarzu domen czy struktur poznawczych nie ograniczają się do relacji międzyjęzykowych, do których zalicza się także przekład. Innymi słowy, aby dany tekst okazał się „nieprzekładalny”, wcale nie musi on zostać poddany operacji przenoszenia z jednego języka do drugiego. 
Badaczka analizuje tłumaczenie na język polski napisanego przez brytyjskiego poetę wiersza na temat Sopotu. Dochodzi do wniosku, że na interpretację utworu wpływa zarówno język (angielski lub polski), jak i sam odbiorca i jego „biografia tekstowa” [Tabakowska 2001: 103], np. to, czy odwiedził Sopot i jak wiele wie o tym miejscu.

To m.in. te indywidualne różnice sprawiają, że osiągnięcie stuprocentowej ekwiwalencji jest niemożliwe. Mimo to tłumacz zwykle występuje w roli - nigdy idealnie obiektywnego, ale jednak - mediatora pomiędzy tekstem napisanym w jednym języku a w pewnej mierze wyobrażoną, „uśrednioną” grupą użytkowników innego języka. Nie jest to bezzasadne - ta grupa, choć złożona z jednostek, dzieli pewien „inwentarz domen czy struktur poznawczych”. Wracając do przykładu z książki Tabakowskiej, przeciętnemu (co oczywiście nie oznacza, że każdemu) Polakowi Sopot kojarzyć się będzie z miejscowością, którą sam odwiedził, albo z obrazem zaczerpniętym z mediów, literatury, opowieści znajomych itd. Wiersz odczytywany przez nieznającego polskich realiów Brytyjczyka z dużym prawdopodobieństwem przywoła wspomnienia np. z Brighton czy innej znanej mu miejscowości nadmorskiej [Tabakowska 2001: 103-104].

W przypadku analizowanej prozy Schulza należy założyć znacznie większą rozbieżność struktur poznawczych użytkowników języka oryginału i języka przekładu, co stanowi kolejny czynnik wykluczający pełną ekwiwalencję. Dokładne odwzorowanie elementów przestrzeni wejściowych amalgamatu i, co za tym idzie, całej jego struktury nie zostałoby osiągnięte nawet przy bardzo wiernym tłumaczeniu poszczególnych wyrazów i fraz. Właściwy przekład słowa „łopuchy” (łopian większy, Arctium lappa to po chińsku niubang) Wei-Yun Lin-Górecka identyfikuje jako wciąż niecałkowicie ekwiwalentny z powodu innych, wynikających z rozbieżnych doświadczeń, skojarzeń z tą rośliną u Polaków i Tajwańczyków - dla większości tych drugich „łopian to zdrowe, smaczne warzywo, którego korzeń można wykorzystać do zupy, sałatki lub innych dań” [Lin-Górecka 2013: 118]. Kognitywiści powiedzieliby, że Polacy i Tajwańczycy mają różne wyidealizowane modele poznawcze łopianu. Należy w tym miejscu zaznaczyć, że tak dokładne tłumaczenie nazwy gatunku rośliny należy do rzad- 
kości w przekładzie polsko-chińskim i chińsko-polskim. Flora Azji wschodniej różni się znacznie od roślinności wschodnioeuropejskiej. Nazwy roślin w jednym miejscu pospolitych, nieprzykuwających uwagi, kilka tysięcy kilometrów dalej sprawiają wrażenie dziwnych, egzotycznych, a czasem nadmiernie fachowych, kiedy dokładne określenie gatunku wymaga użycia nazwy dwuczłonowej albo nawet łacińskiej. Dlatego w takich sytuacjach rezygnuje się często z dokładnych określeń na rzecz np. nazwy generycznej, rodzajowej, a nie gatunkowej, albo zastępuje się je nazwą podobnego, powszechnego w kręgu kulturowym języka docelowego gatunku. Tak też przetłumaczona jest część nazw u Lin-Góreckiej i Lu Yuana.

Kognitywna analiza obrazowania w opisie ogrodu wykazała, że obydwa przekłady nie są w pełni ekwiwalentne, różnią się także między sobą. Rozbieżności pomiędzy wersjami tekstu nie są na tyle duże, żeby całkowicie zmienić skonstruowany przez Schulza amalgamat pojęciowy: we wszystkich przypadkach zachowuje on te same przestrzenie wejściowe. Zmodyfikowana zostaje jednak ich zawartość, szczególnie w przypadku przestrzeni wejściowej sierpniowego żywiołu i dzikiego zwierzęcia. To powoduje przesunięcie opisywanych elementów na skali empatii, wpływając na odbiór tekstu przez potencjalnego czytelnika, w tym natężenie odczucia niesamowitości. Amalgamat w przekładzie Wei-Yun Lin-Góreckiej jest nieco uboższy niż u Lu Yuana, można go za to określić jako bardziej spójny i harmonijny. Ocena porównawcza ekwiwalencji czy wręcz jakości przekładów może być różna. Rojo i Ibarretxe-Antuñano, według których celem tłumaczenia jest zbudowanie funkcjonalnej całości, prawdopodobnie przyznaliby palmę pierwszeństwa Lin-Góreckiej. Mniej jednoznaczna byłaby ewaluacja według standardu „zbieżności obrazów” Tabakowskiej. Niezależnie jednak od ocen merytorycznych obydwu chińskojęzycznych wersji prozy Schulza kognitywna metoda analizy przekładu daje możliwość odsłonięcia procesów myślowych, które rządzą tłumaczeniem i jego interpretacją, oraz pozwala wskazać, jak nawet drobne różnice w leksyce czy składni wpływają na modyfikację wytwarzanych w tekście struktur pojęciowych. 


\section{Bibliografia}

Boase-Beier Jean (2011), A Critical Introduction to Translation Studies, Continuum, London.

Brône Geert, Vandaele Jeroen, red. (2009), Cognitive Poetics: Goals, Gains and Gaps, De Gruyter Mouton, Berlin.

Crisp Peter (2003), Conceptual Metaphor and Its Expressions, w: Cognitive Poetics in Practice, red. Joanna Gavins, Gerard Steen, Routledge, London, s. 99-113.

Danaher David S. (2006), Poetyka kognitywna a literackość: analogia metaforyczna w „Annie Kareninie”, przel. Małgorzata Majewska, „Przestrzenie Teorii”, nr 6, s. 277-298, https://doi.org/10.14746/ pt.2006.6.16.

Fauconnier Gilles, Turner Mark (2019), Jak myślimy. Mieszaniny pojęciowe i ukryta złożoność umystu, przeł. Izabela Michalska, Fundacja Augusta hr. Cieszkowskiego, Warszawa.

Fu Xiaowei, Wang Yi (2008), The Influence of Jewish Literature in China, w: The Jewish-Chinese Nexus. A Meeting of Civilizations, red. M. Avrum Ehrlich, Routledge, Abingdon-New York, s. 118-132.

Gavins Joanna, Steen Gerard, red. (2003), Cognitive Poetics in Practice, Routledge, London.

Iversen Margaret (2006), Im blinden Feld: Hopper und das Unheimliche, w: Orte des Unheimlichen: Die Faszination verborgenen Grauens in Literatur und bildender Kunst, red. Klaus Herding, Gerlinde Gehrig, Vandenhoeck \& Ruprecht, Göttingen, s. 272-299.

Jakubów Zofia (2018), Kognitywna analiza opisu zmierzchu we fragmencie „Sklepów cynamonowych” Brunona Schulza, w: Orientaliści kognitywnie, red. Joanna Jurewicz, Elipsa, Warszawa, s. 67-78.

Jurewicz Joanna (2018), Wprowadzenie, w: Orientaliści kognitywnie, red. Joanna Jurewicz, Elipsa, Warszawa, s. 7-14.

Lakoff George, Johnson Mark (1988), Metafory w naszym życiu, przeł. Tomasz Krzeszówski, pIw, Warszawa.

Lakoff George, Johnson Mark (1999), Philosophy in the Flesh: The Embodied Mind and Its Challenge to Western Thought, Basic Books, New York.

Lin-Górecka Wei-Yun (2013), Transpacyficzna transcendencja. O ttumaczeniu Schulza na język chiński, „Schulz/Forum”, nr 2, s. 113-118.

Nie Liping (2020), Lu Yuan: gen ciyu jinxing bodou yu hezuo, wei jianli meihao zhixu nuli, „Xin Jingbao”, [dostęp: 8 września 202o], https://tinyurl.com/s8pcuhy8. 
Rojo Ana, Ibarretxe-Antuñano Iraide (2013), Cognitive Linguistics and Translation Studies: Past, Present and Future, w: Cognitive Linguistics and Translation: Advances in Some Theoretical Models and Applications, red. Ana Rojo, Iraide Ibarretxe-Antuñano, De Gruyter Mouton, Berlin, s. 3-30.

Schulz Bruno (1989), Opowiadania. Wybór esejów i listów, red. Jerzy Jarzębski, Ossolineum, Wrocław.

Schulz Bruno (2016), Eyu Jie: Bulunuo Shuerci xiaoshuo quanji, przeł. Lin Weiyun, [dostęp: 4 września 2020], https://yuedu.163.com/book_ reader/37bcdo3oad1f43d188bb9e23ed62995e_4, Guilin.

Schulz Bruno (2017), Rouguise puzi ji qita gushi, przeł. Lu Yuan, Sichuan Renmin Chubanshe, [dostęp: 4 września 2020] https://yuedu.163. com/book_reader/b12c2506de8b4c8b92b5f17bf42daa50_4, Chengdu.

Stownik języka polskiego PWN (2020), Kożuch [hasło], [dostęp: 16 września 2020], https://tinyurl.com/49dxwuva.

Stockwell Peter (2006), Poetyka kognitywna. Wprowadzenie, red. Elżbieta Tabakowska, przeł. Anna Skucińska, Universitas, Kraków.

Tabakowska Elżbieta (2001), Językoznawstwo kognitywne a poetyka przekładu, przeł. Agnieszka Pokojska, Universitas, Kraków.

Wojda Dorota (2009), Bruno Schulz and the Magical Realism of Gabriel García Márquez in „One Hundred Years of Solitude”, w: (Un)masking Bruno Schulz: New Combinations, Further Fragmentations, Ultimate Reintegrations, red. Dieter De Bruyn, Kris Van Heuckelom, Rodopi, Amsterdam-New York, s. 173-193.

Wu Lan (2010), Bruno Schulzw Chinach, „Postscriptum Polonistyczne”, nr 2 (6), s. 253-26o.

Yang Deyou (2011), Shuerci zuopin yishi, „Mingzuo Xinshang”, nr 6, s. 5-17.

\section{Zofia Jakubów}

\section{How to Describe Galician Suburbs of the Past in Contemporary Chinese? A Cognitive Analysis of the Translations of Bruno Schulz's The Cinnamon Shops}

The article is an analysis of the description of the garden in Bruno Schulz's The Cinnamon Shops (Sklepy cynamonowe) and its two translations into Chinese. Wei-Yun Lin-Górecka has translated Schulz's prose from the original Polish, while Lu Yuan's translation is primarily based on English versions of his work. The analysis employs methods drawn from cognitive poetics and some elements of cognitive theory of translation, especially Elżbieta Tabakowska's ideas on imagery and translation equivalence. The study 
helped characterize a complex conceptual blend found in the description and trace structural changes caused by the translators' specific decisions. The translations are characterized by a relatively high level of equivalence. The conceptual blends they comprise differ from the one created by Bruno Schulz mostly in terms of the described elements' positions on the empathy scale, which are mainly dependent upon the translators' manner of using the devices of animation and anthropomorphism.

Keywords: Bruno Schulz; Sklepy cynamonowe; The Cinnamon Shops; cognitive poetics; Polish-Chinese translation.

Zofia Jakubów - doktor, adiunkt w Zakładzie Sinologii Wydziału Orientalistycznego Uniwersytetu Warszawskiego. Jej zainteresowania naukowe skupiają się na współczesnej chińskiej literaturze i kulturze. Jest autorką monografii Znużeni nowoczesnością. Społeczeństwo konsumpcyjne i wartości materialne w twórczości Muronga Xuecuna i Li Shijianga oraz licznych artykułów poświęconych współczesnej literaturze chińskiej. Adres e-mail: zofia. jakubow@uw.edu.pl. 
